\title{
Kinetics and Regulation of Human Keratinocyte Stem Cell Growth in Short-Term Primary Ex Vivo Culture

\author{
Cooperative Growth Factors from Psoriatic Lesional T Lymphocytes Stimulate Proliferation among \\ Psoriatic Uninvolved, But Not Normal, Stem Keratinocytes
}

\author{
Zsuzsanna Bata-Csorgo, Craig Hammerberg, John J. Voorhees, and Kevin D. Cooper \\ Immunodermatology Unit and Department of Dermatology, University of Michigan, and the Ann Arbor Veterans Affairs Hospital, Ann \\ Arbor, Michigan 48109
}

\begin{abstract}
Flow cytometric analysis of primary ex vivo keratinocyte cultures demonstrated that stem cells, $\left(\beta 1\right.$ integrin ${ }^{+}$, keratin $1 /$ keratin $10\left[\mathrm{K1}_{\mathrm{K} 10}{ }^{-}\right]$, proliferating cell nuclear antigen [PCNA ${ }^{-}$] [Bata-Csorgo, Zs., C. Hammerberg, J. J. Voorhees, and K. D. Cooper. 1993. J. Exp. Med. 178:1271-1281]) establish such cultures. This methodology also enabled the quantitation of synchronized recruitment of these cells from $G_{0}$ into $G_{1}$ of the cell cycle (PCNA expression), which preceded bright $\beta 1$ integrin expression. ( $\beta 1$ integrin ${ }^{\text {bright }}$ expression has been shown to be a characteristic feature of keratinocyte stem cells in culture (Jones, P. H., and F. M. Watt. 1993. Cell. 73:713-724). Using the above assay, we determined whether lesional $T$ lymphocytes in psoriasis could be directly responsible for the induction of the stem cell hyperproliferation that is characteristic of this disease. Indeed, $\mathrm{CD}^{+} \mathrm{T}$ lymphocytes, cloned from lesional psoriatic skin and stimulated by immobilized anti-CD3 plus fibronectin, promoted psoriatic uninvolved keratinocyte stem cell proliferation via soluble factors. This induction appeared to be through accelerated recruitment of stem cells from their quiescent state $\left(\mathbf{G}_{0}\right)$ into cell cycle. By contrast, normal keratinocyte stem cells exhibited no such growth stimulation. Supernatants exhibiting growth induction all contained high levels of GM-CSF and $\gamma$-IFN, low IL-3 and TNF- $\alpha$, and variable IL-4. Only anti- $\gamma$-IFN antibody was able to neutralize growth stimulatory activity of the supernatants on psoriatic uninvolved keratinocyte stem cells. However, because recombinant $\gamma$-IFN alone inhibited growth in this assay, these data suggest that, in psoriasis, $\gamma$-IFN acts cooperatively with other growth factors in the immune induction of cell cycle progression by the normally quiescent stem cell keratinocytes. (J. Clin. Invest. 1995. 95:317-327.) Key words: $\beta 1$ integrin $\cdot$ keratin $1 /$ keratin $10 \cdot \gamma$-IFN $\bullet$ proliferating cell nuclear antigen $\cdot$ flow cytometry
\end{abstract}

Address correspondence to Zsuzsanna Bata-Csorgo, MD, Immunodermatology Unit, University of Michigan, R5548 KresgeI/Campus Box 0530, Ann Arbor, MI 48109-0530. Phone: 313-747-0091; FAX: 313747-1944. 1994.

Received for publication 14 April 1994 and in revised form 11 July

J. Clin. Invest.

(C) The American Society for Clinical Investigation, Inc.

$0021-9738 / 95 / 01 / 0317 / 11 \quad \$ 2.00$

Volume 95, January 1995, 317-327

\section{Introduction}

Recent progress in the identification and understanding of epidermopoietic subsets has highlighted the ability of normally slow cycling stem cells to increase their proliferation and generation of differentiating progeny in response to appropriate signals (1-3). We have previously defined different subsets of proliferative cells in the in vivo human epidermis based on multiparameter flow cytometric analysis using specific antibodies related to cell differentiation ( $\beta 1$ integrin, $\mathrm{K} 1 / \mathrm{K} 10$ keratins ) and cell cycle (proliferating cell nuclear antigen [PCNA] ${ }^{1}$ ), in combination with flow cytometric quantitation of cellular DNA content and optical characteristics of the cells (4). The $\beta 1$ integrin marked both of the potentially proliferative subsets in normal epidermis.

One subset was $\beta 1$ integrin ${ }^{+} \mathrm{K} 1 /{\mathrm{K} 10^{-}}^{-}$and contained basal keratinocytes. By all current definitions, the keratinocyte stem cell population must be contained within this $\beta 1$ integrin $^{+} \mathrm{K} 1 /$ $\mathrm{K}_{10} 0^{-}$population. This population in the normal epidermis is slow cycling with more than $95 \%$ of them in $\mathrm{G}_{0}$ phase $\left(\mathrm{PCNA}^{-}\right.$) (4), a widely accepted feature of stem cells (5). Cells in this population do not express $\mathrm{K} 1 / \mathrm{K} 10$ keratins, one of the first signs of differentiation in keratinocytes, indicating that they are in an undifferentiated state, another accepted criteria of stem

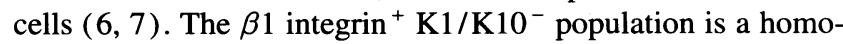
geneous population that is small in cell size and simple in cytoplasmic structure (4). This population is similar to the stem cell population in human epidermis described by Lavker and Sun (6) which is small, nonserrated, slowly cycling, and primitive in cytoplasmic structure.

The other proliferative subset of normal epidermis was $\beta 1$ integrin $^{+} \mathrm{K} 1 / \mathrm{K}_{10}{ }^{+}$, this population was basal, slightly suprabasal, and contained highly proliferative, larger cells with more complex cytoplasmic structure, which is the phenotype characteristic of cells in in vivo epidermis which have committed to differentiation (K1/K10 expression) but undergo a transient period of proliferation before terminal differentiation (transient amplifying cells).

An in vivo human disease state in which normally slowly cycling epidermal progenitors hyperproliferate is psoriasis. In this state, the $\beta 1$ integrin $^{+} \mathrm{K} 1 / \mathrm{K}_{10} 0^{-}$stem cell-containing population has emerged from its normal $\mathrm{G}_{0}$ state into virtually $100 \%$ active cell cycle status (4). Understanding the signals for this dramatic shift into cell cycle may provide important information on stem cell physiology and pathophysiology, and may also yield therapeutic application in psoriasis.

1. Abbreviations used in this paper: $\mathrm{K} 1 / \mathrm{K} 10$, keratin $1 /$ keratin 10 ; KBM, keratinocyte basal medium; MNC, mononuclear cell; PCNA, proliferating cell nuclear antigen; PI, propidium iodide. 
An early cellular event in the development of psoriatic lesions is the infiltration of the target tissue by macrophages and activated $\mathrm{T}$ lymphocytes (8-10). Lesional psoriatic skin contains activated memory $\mathrm{T}$ lymphocytes $(10-15)$ whose production of mRNA for lymphokines such as IL-2, $\gamma$-IFN, and TNF- $\alpha$ is elevated relative to normal or uninvolved psoriatic epidermis (16). That the $\mathrm{T}$ cell activation and soluble lymphokine production plays a crucial role in the maintenance of epidermal hyperplasia in the psoriatic lesion is indicated by the beneficial clinical effect of such immunosuppressive agents as cyclosporin A, FK 506, anti-CD3, and anti-CD4 in the treatment of psoriasis (17-22). Psoriatic keratinocytes do appear to have been modulated by $\mathrm{T}$ cell lymphokines in vivo, because they abnormally express class II MHC and IP-10 molecules uniquely induced on keratinocytes by the T cell product $\gamma$-IFN (2327 ). Indeed, $T$ cells producing $\gamma$-IFN have been cloned from psoriatic lesions (28) and they appear to be able to induce keratinocyte class II MHC and intracellular adhesion molecule expression (29) and growth of keratinocytes which have been multiply passaged in vitro (30). Thus, $\mathrm{T}$ cells are a likely source of signals for keratinocyte stem cell activation, either directly or indirectly.

Testing the responsiveness of human epidermal stem cells to putative growth regulatory signals released by $\mathrm{T}$ lymphocytes or other cells requires an understanding of the behavior of stem cells in ex vivo culture. Although much information is available regarding growth regulation of long-term, passaged keratinocytes, such cells are clearly modulated by the conditions associated with repeated subculture. Thus, passaged keratinocytes differ from in vivo epidermal cells in their expression of cytoskeletal proteins, membrane composition, cytokines, and surface integrins $(1,31-34)$. In addition, passaged keratinocyte cultures differ from in vivo epidermis in their composition of proliferative compartment cells, because cell cycle quiescent $\left(\mathrm{G}_{0}\right)$ stem cells are underrepresented and highly cycling clonogenic stem cells and transient amplifying cells are overrepresented (35). It would thus be useful to manipulate human epidermal stem cells in a state as close to the in vivo situation as possible.

In this study, we use flow cytometric methods to demonstrate the kinetics of normal stem cell behavior during establishment of primary in vitro human epidermal cell cultures. By quantitating their number, cell cycle status, and differentiation state in the first few days of primary culture, human epidermal stem cells could thus be examined for their responsiveness to modulation in their fresh ex vivo state before modulation by repeated subcultures.

Using $\mathrm{T}$ cells cloned from lesional psoriatic skin, we present data showing that lesional psoriatic $\mathrm{T}$ cells activated by immobilized anti-CD3 plus fibronectin produce factors that induce increased keratinocyte colony formation as well as increased cell cycle entry by the normally quiescent stem cell population. Furthermore, the $\beta 1$ integrin $^{+} \mathrm{K} 1 /{\mathrm{K} 10^{-}}^{-}$keratinocyte stem cells in psoriatic uninvolved epidermis are significantly hyperresponsive to the growth stimulatory lymphokine milieu relative to $\beta 1$ integrin ${ }^{+} \mathrm{K} 1 / \mathrm{K}_{10}{ }^{-}$normal keratinocytes. Neutralization experiments suggested that $\gamma$-IFN, although growth inhibitory on its own, acts cooperatively with other $\mathrm{T}$ cell-produced growth factors to cause growth induction. These data provide direct evidence that human epidermal stem cells are responsive to growth stimulatory signals released by $\mathrm{T}$ lymphocytes, such as those in psoriatic lesions, and provide a mechanism by which keratinocyte stem cells can increase their proliferation in response to local stimuli.

\section{Methods}

Flow cytometric identification of proliferative keratinocyte subsets. Epidermal cell suspensions were prepared from normal deep keratomes by treatment with dispase (Collaborative Biomedical Products, Bedford, MA) (overnight $4^{\circ} \mathrm{C}$ ) followed by removal of the dermis, then treatment of the epidermis with $0.25 \%$ trypsin (United States Biochemical Corporation, Cleveland, $\mathrm{OH})\left(15-20 \mathrm{~min}, 37^{\circ} \mathrm{C}\right)$. Cells were plated into 6-well culture plates $\left(1 \times 10^{6} \mathrm{cells} / \mathrm{ml}, 2 \mathrm{ml} / \mathrm{well}\right)$ and cultured in keratinocyte basal media (KBM, Keratinocyte-SFM media without bovine pituitary extract, and EGF; Gibco Laboratories, Grand Island, NY) supplemented with 1\% FBS (Hyclone, Logan, UT). At different time points after initiation of the cultures the cells were briefly trypsinized $(0.025 \%$ trypsin $+0.01 \%$ EDTA $)$, collected and fixed in $70 \%$ cold ethanol at $-20^{\circ} \mathrm{C}$ and stained with the following monoclonal antibodies: anti- $\beta 1$ integrin (4B4, 4B4-RD1 anti- $\beta 1$ integrin antibody directly conjugated to phycoerythrin [PE]; Coulter Immunology, Hialeah, FL) 1:20 dilution, anti-K1/K10 (AE2) 1:50 dilution, anti-vimentin (both from ICN Biomedicals Inc., Costa Mesa, CA) 1:800 dilution, antiPCNA (Boehringer Mannheim, Indianapolis, IN) 1:100 dilution and isotype controls (purified mouse IgG1 and IgG2a, Sigma Chemical Co., St. Louis, MO; mouse IgG1-RD1, Coulter Immunology). Goat antimouse IgG1 and IgG2a FITC (Boehringer Mannheim) was used as secondary antibody at 1:100 dilution and $10 \%$ normal goat serum $(\mathrm{Ce}$ darlane Laboratories, Hornby, Ontario, Canada) to block nonspecific binding. After monoclonal antibody staining, the cells were resuspended in propidium iodide (PI) $(50 \mu \mathrm{g} / \mathrm{ml})$ with RNase A ( $100 \mathrm{U} / \mathrm{ml}$, both from Sigma Chemical Co.) and incubated at room temperature for 30 min. Samples were stored at $4^{\circ} \mathrm{C}$ and analyzed within $24 \mathrm{~h}$ by flow cytometer. In one experiment cells from a 7-d culture were harvested and stained with anti- $\beta 1$ integrin before ethanol fixation to determine whether the bright staining was due to intracellular or surface $\beta 1$ integrin. Flow cytometry was performed using an Epics Elite Flow cytometer (Coulter Cytometry, Hialeah, FL), as previously described (4). Cell aggregates were eliminated from DNA analysis based on the ratio of integrated to peak fluorescence of PI. Data (an average of 30,000 events from each sample) were collected on a logarithmic scale for FITC and on a linear scale for PI, and stored in Listmode. Data was analyzed using Coulter Elite software (Coulter Cytometry).

Initiation of psoriatic $T$ cell clones. The criteria for punch biopsy of lesional psoriasis for cloning $\mathrm{T}$ cells was that the lesion be expanding, small, inflammatory, psoriatic papules of patients who had not received internal medication $1 \mathrm{mo}$, and topical treatment $2 \mathrm{wk}$ before the biopsy. The dermis was cut away and the remaining epidermis cut into several small pieces which were then placed into a 24-well tissue culture dish in RPMI 1640 media (Whittaker M. A. Bioproducts, Inc., Walkersville, MD) supplemented with 10\% AB serum (North American Biological, Miami, FL) and a low dose $(50 \mathrm{U} / \mathrm{ml})$ of recombinant human IL-2 (Collaborative Biomedical Products) to selectively propagate in vivo activated $\mathrm{T}$ cells expressing high affinity IL-2 receptors. After a 24-h incubation $\left(37^{\circ} \mathrm{C}, 5 \% \mathrm{CO}_{2}\right)$ the pieces were transferred to a second 24 well plate for another 24-h incubation. Cells were then harvested from the dishes, combined, washed 3 times, and replated in the above media. The next day the cells were cloned by limiting dilution and plated into 96-well v-bottom plates $(0.3$ cells/well $)$ together with allogeneic gamma irradiated (5,000 rad) Ficoll-Hypaque purified peripheral blood mononuclear cells $\left(\mathrm{MNC}, 0.5 \times 10^{6} /\right.$ well) and $1 \mu \mathrm{g} / \mathrm{ml} \mathrm{PHA} \mathrm{(Bur-}$ roughs-Wellcome, Research Triangle Park, NC). Cloning wells containing positive growth were expanded into v-bottom 96-well plates, then 24-well plates, frozen in 90\% FBS and 10\% DMSO, and stored in liquid $\mathrm{N}_{2}$. Cloned psoriatic lesional $\mathrm{T}$ cells were immunophenotyped with anti-CD3, anti-CD4, anti-CD8, anti-TCR $\gamma / \delta$, and anti-TCR $\alpha /$ $\beta$ antibodies, using appropriate isotype controls (Becton Dickinson, Mountain View, CA) and analyzed by flow cytometry. 
$T$ cell activation for generation of supernatants for stimulation of epidermal cells. Frozen $\mathrm{T}$ cells from the different clones were thawed and placed in AIM V (Gibco Laboratories) + 10\% FBS [Hyclone] $+50 \mathrm{U} / \mathrm{ml} \mathrm{rIL}-2$ (Collaborative Biomedical Products) media in 24well plates and then stimulated with PHA $(1 \mu \mathrm{g} / \mathrm{ml})$ and allogeneic MNCs $\left(0.5 \times 10^{6} /\right.$ well $)$. After $48 \mathrm{~h}$ the MNCs were removed from the cultures by Ficoll-Hypaque density gradient centrifugation. 10-12 $\mathrm{d}$ were required for the $\mathrm{T}$ cells to reach resting state after PHA plus MNC activation, at which time they were then plated on fibronectin and anti-CD3-coated culture dishes in serum-free and IL-2-free AIM V media. Before cell plating the culture plates were coated initially with anti-CD3 $\left(1 \mu \mathrm{g} / \mathrm{ml}\right.$ ) overnight $4^{\circ} \mathrm{C}$, washed with PBS (Gibco Laboratories) and then coated with fibronectin (Sigma Chemical Co.) $(20 \mu \mathrm{g} /$ $\mathrm{ml}$ ) overnight $4^{\circ} \mathrm{C}$ and washed with PBS, as previously described (36). Supernatants were collected $48 \mathrm{~h}$ after plating, sterile filtered, and stored at $-70^{\circ} \mathrm{C}$. Lymphokine production by activated lesional psoriatic $\mathrm{T}$ cells was determined by using ELISA kits for GM-CSF, IL-3, IL-4 (R\&D Systems, Inc., Minneapolis, MN), $\gamma$-interferon (Genzyme Corp., Boston, MA) and TNF- $\alpha$ (PharMingen, San Diego, CA).

Clonal growth assay. Epidermal cell suspensions were prepared from normal and uninvolved psoriatic keratomes as described above. Cells were plated into 6-well culture plates $\left(1 \times 10^{6} \mathrm{cells} / \mathrm{ml}, 2 \mathrm{ml} /\right.$ well) in KBM (Gibco Laboratories) media supplemented with $1 \%$ FBS Activated $\mathrm{T}$ cell supernatants and AIM V media, as control, were diluted at 1:10 with $\mathrm{KBM}$ and added at the time of culture initiation to the cultures $(200 \mu 1 /$ well $)$. The media was changed on every third day, each time supplemented with activated $\mathrm{T}$ cell supernatant or AIM V media as described. After 2 wk plates were fixed with $1 \%$ formalin and stained with Rhodamine B (Sigma Chemical Co.) (37).

Short-term epidermal proliferation assay. Freshly isolated psoriatic uninvolved and normal epidermal cells were plated in 6-well culture plates at $1 \times 10^{6}$ cells $/ \mathrm{ml}, 2 \mathrm{ml} /$ well, and cultured for $72 \mathrm{~h}$ in the presence of activated psoriatic $\mathrm{T}$ cell supernatant $(4 \mathrm{~F} 4,4 \mathrm{~F} 1)$ or AIM $\mathrm{V}$ medium diluted 1:100 in KBM $+1 \%$ FBS. Cells were then fixed in $70 \%$ ethanol and stained with anti- $\beta 1$ integrin, anti-K1/K10, and antivimentin as above. DNA content was determined by staining with propidium iodide. Samples were analyzed by flow cytometry.

Neutralization experiments. In some experiments, lymphokines in the psoriatic activated $\mathrm{T}$ cell supernatants were neutralized with monoclonal antibodies. The following neutralizing antibodies were separately added to the epidermal cell cultures before addition of the activated $\mathrm{T}$ cell supernatant (4F4): mouse anti-human IFN $\gamma$ (Genzyme Corp.), $4.5 \mu \mathrm{g} / \mathrm{ml}$; goat anti-human IL-3, $3 \mu \mathrm{g} / \mathrm{ml}$; goat anti-human GMCSF (both from R\&D Systems, Inc.), $20 \mu \mathrm{g} / \mathrm{ml}$; mouse anti-human TNF- $\alpha$ (Boehringer Mannheim), $10 \mu \mathrm{g} / \mathrm{ml}$. Isotype controls were mouse IgG2a and IgG1 (Sigma Chemical Co.) and goat IgG (R\&D Systems, Inc.), at identical concentrations. The concentrations were calculated to achieve a 100-fold excess of neutralizing activity based upon the known amounts of lymphokines in the supernatants and the neutralizing activity of each antibodies.

The above described short-term epidermal cell proliferation assay was used to test the effect of human recombinant $\gamma$-IFN (Collaborative Biomedical Products, at 10 and $100 \mathrm{U} / \mathrm{ml}$ ) on keratinocyte stem cells.

Statistical analysis. Pairwise Student's $t$ test was used to compare keratinocyte stem cell growth in the presence of $T$ cell supernatant and control media in the short-term proliferation assays.

\section{Results}

The $\beta 1$ integrin ${ }^{+} \mathrm{K} / \mathrm{K} \mathrm{O}^{-}$stem cell-containing keratinocyte subset is responsible for establishing colonies in primary in vitro cultures of human epidermal keratinocytes. Normal fresh ex vivo epidermal cells were plated in $\mathrm{KBM}+1 \% \mathrm{FBS}$, and at different time points the cells were harvested and stained with anti- $\beta 1$ integrin, anti-K1/K10, and propidium iodide (PI). At $24 \mathrm{~h}$, the cultured cells exhibited characteristics by flow cytometry identical to freshly isolated cells (Fig. $1 a$ ) (4). As compared to the isotype control-stained preparation (Fig. $1 a$, third column), essentially all proliferating cells were $\beta 1$ integrin $^{+}$(Fig. $1 a$, first column, $y$ axis) $\left(S / G_{2} / M\right.$ phase is indicated along the $x$ axis by cells with greater than diploid DNA content by PI intensity).

These $\beta 1$ integrin $^{+}$cells at $24 \mathrm{~h}$ can be divided into two proliferating cell populations by $\mathrm{K} 1 / \mathrm{K} 10$ expression (Fig. $1 a$, second column, $y$ axis); (a) $\mathrm{K} 1 / \mathrm{K} 10^{-}$cells containing the cycling compartment of the stem cell population (a minor $\mathrm{S}$ / $\mathrm{G}_{2} / \mathrm{M}$ population that lies below the horizontal cursor denoting positive/negative fluorescence) and (b) $\mathrm{K} 1 / \mathrm{K} 10^{+}$cells representing the transient amplifying cell population which has committed to differentiation in vivo but is still capable of proliferation (major population of cells in $S / G_{2} / M$ phase above the cursor).

After $72 \mathrm{~h}$ of culture, a distinct proliferating cell population begins to appear in the cultures, which has very bright $\beta 1$ integrin expression (Fig. $1 b$, first column, arrow) while a few K1/ $\mathrm{K} 0^{+}$cells of moderate $\beta 1$ integrin expression with greater than diploid DNA content are still present (Fig. $1 b$, second column, above the cursor). In contrast to fresh ex vivo cells, some cells in $S / G_{2} M$ phase are $\beta 1$ integrin $^{-}$at $72 \mathrm{~h}$ in the cultures (Fig. $1 b$, column 1 ). The $\beta 1$ integrin $^{\text {bright }}$ population (arrow) contains a higher cycling pool than the $\beta 1$ integrin $^{\text {dim }}$ or ${ }^{-}$cells in the culture, as determined by the number of cells with greater than diploid DNA content in each population (32.5\% of $\beta 1$ integrin $^{\text {bright }}$ cells are in $\mathrm{S} / \mathrm{G}_{2} / \mathrm{M}$ phase, whereas only $5.1 \%$ of $\beta 1$ integrin $^{\mathrm{dim}}$ or $^{-}$cells are in cycle [Fig. $1 b$, column 1]).

After $7 \mathrm{~d}$ of culture, almost all the cells are $\beta 1$ integrin $^{\text {bright }}$ $\mathrm{K} 1 / \mathrm{K}^{-} 0^{-}$(Fig. $1 c$, left and middle columns) and are still characterized by a high cycling pool $\left(\mathrm{S} / \mathrm{G}_{2} / \mathrm{M}: 40.3 \%\right)$. At this time, small colonies (5-6 cells) of monolayered cells can be seen in the cultures. (Cells were also stained at $7 \mathrm{~d}$ with and without prior ethanol fixation and similar staining pattern was observed in both cases, indicating that the bright $\beta 1$ integrin expression is related to the cell surface, data not shown.) At culture confluency, $\mathrm{K} 1 / \mathrm{K} 10$ expression appears on the majority of the cells (Fig. $1 d$. column 2 ) and cells with lower expression of $\beta 1$ integrin are also present. $33.2 \%$ of the cells are in $\mathrm{S} / \mathrm{G}_{2} /$ $M$ phase, indicating that the proliferation of the cells in the confluent culture is slowing, either as a result of cells becoming too differentiated to cycle or as a result of having a longer cell cycle time. Very few cells are $\beta 1$ integrin $^{-}$in the culture $(6.9 \%)$, but the number of $\mathrm{K} 1 / \mathrm{K}^{-} 0^{-}$cells is substantial ( $18.5 \%$ ) indicating that a $\beta 1$ integrin $^{+} \mathrm{K} 1 / \mathrm{K} 10^{-}$cell population (stem cell phenotype) remained present throughout the primary culture period. These cells are likely to represent the $\beta 1$ integrin $^{\text {bright }}$ cells responsible for establishing colonies in subcultures (1).

Keratinocyte colony formation in vitro can be regulated by the soluble products of T lymphocytes; growth regulatory effect correlates with the lymphokine profile of cloned psoriatic lesional $T$ cell subsets. Early psoriatic lesions were cultured in low concentration of IL-2 to propagate and clone in vivo- activated T cells expressing high affinity IL-2 receptors. After cloning, T cells were plated on anti-CD3- and fibronectin-coated tissue culture dishes in serum-free media. In initial experiments, activated $T$ cell supernatants from 12 different lesional $T$ cell clones were screened by measuring their effect on freshly isolated epidermal cell colony formation in vitro (Fig. 2). At 2 wk of 
$\beta_{1}$ Integrin
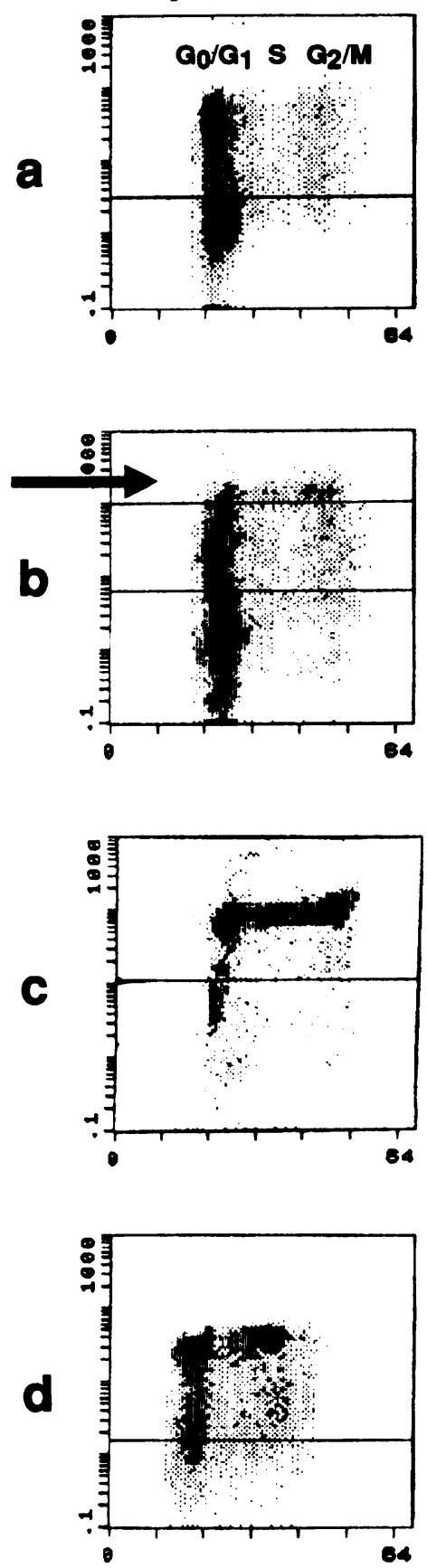

K1/K10
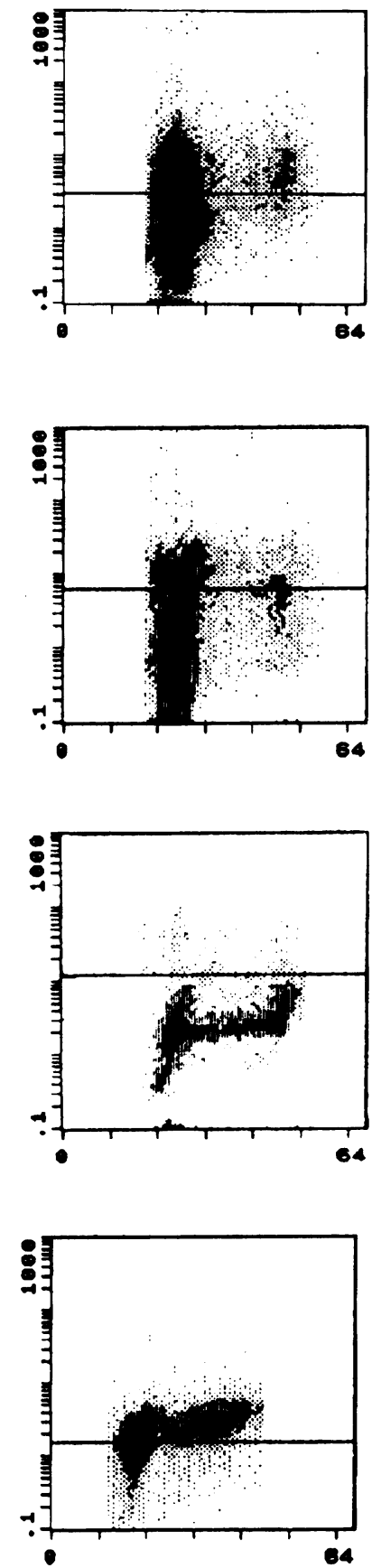

Isotype

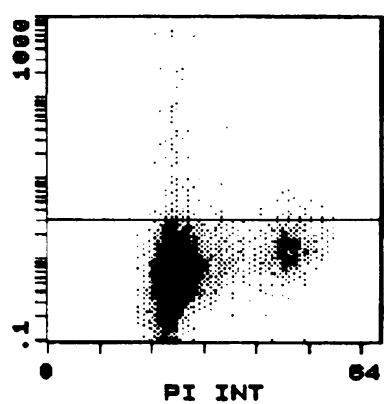

$24 \mathrm{~h}$

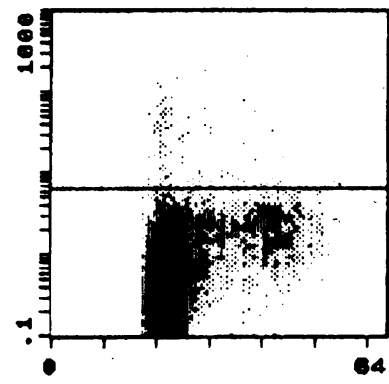

$72 \mathrm{~h}$

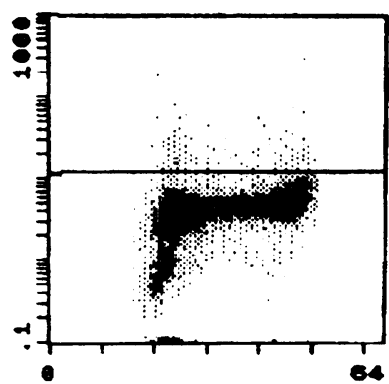

7 d

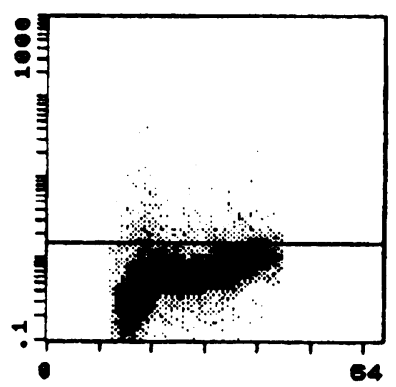

confluent

Figure 1. Flow cytometric identification of keratinocyte subsets in in vitro primary cultures. After various time periods of culture, normal epidermal cells were harvested and fixed in $70 \%$ ethanol, then costained either with anti- $\beta 1$ integrin (FITC) + PI or anti-K1/K10(FITC) + PI. Red fluorescence intensity (PI, shown on linear scale, $x$ axes) quantitates whether the cell is diploid $\left(\mathrm{G}_{0} / \mathrm{G}_{1}\right)$ or has entered cell cycle $\left(\mathrm{S} / \mathrm{G}_{2} / \mathrm{M}\right)$. FITC fluorescence intensity ( $y$ axes) characterizes $\beta 1$ integrin or $\mathrm{K} 1 / \mathrm{K} 10$ positivity. Positive cells are represented by dots above the horizontal cursors, defined by nonspecific isotype staining.

culture, when the colony formation is clear but still sufficiently subconfluent that individual colonies can be determined, the cultures were fixed, stained, and assessed with regard to average colony size and density. Relative to cultures incubated with control media (a serum free lymphocyte medium: AIM V) supernatants from five $T$ cell clones showed a clear growth stimulatory effect both on psoriatic uninvolved and normal kera- tinocytes. This occurred in repeated experiments using different donor keratinocytes (Table I, upper group). In addition, three clones exhibited an inhibitory effect on keratinocyte clonal growth (Table I, lower group) and four clones showed no effect and either a positive response or no response on normal and psoriatic uninvolved keratinocyte growth (Table I, middle group). Thus, heterogeneity of $\mathrm{T}$ cell populations can be dem- 

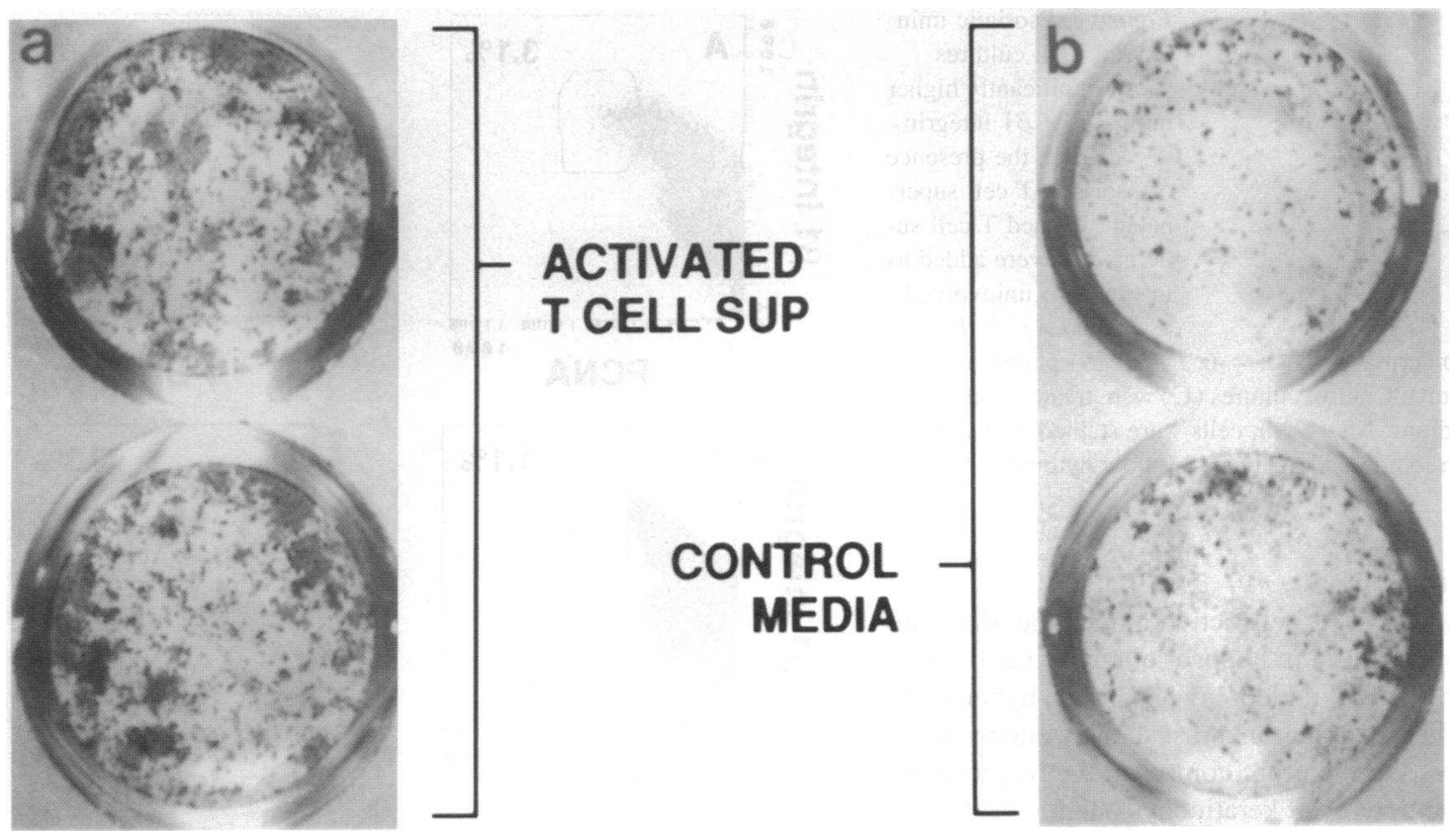

Figure 2. Keratinocyte clonal growth is induced by soluble factors produced by lesional psoriatic T cells. Cloned psoriatic T cells (4F4) were activated with anti-CD3 plus fibronectin in AIM V medium. Their 48-h supernatant $(a)$ or control AIM V media $(b)$ was added at a 1:100 dilution to uninvolved psoriatic epidermal cells plated in KBM $+1 \%$ FBS. The media was freshly supplemented and changed on every third day. After 2 wk of culture, plates were fixed in $1 \%$ formalin and stained with rhodamine $\mathrm{B}$.

onstrated at the clonal level in lesional psoriasis $(15,29)$, and the nature of the heterogeneity includes the capacity to be either growth promoting or growth inhibitory for keratinocytes. Interestingly, $75 \%$ of clones exhibited a positive growth-promoting

Table I. Cloned Psoriatic T Cell Effects on Colony Formation by Freshly Obtained Psoriatic Uninvolved and Normal Epidermal Cells

\begin{tabular}{ccc}
\hline Cloned T cells $^{\ddagger}$ & Psoriatic uninvolved & Normal \\
\hline $4 \mathrm{~F} 1$ & $+(1 / 1)^{*}$ & $+(3 / 3)$ \\
$4 \mathrm{~F} 4$ & $+(7 / 7)$ & $+(3 / 3)$ \\
1C11 & $+(3 / 3)$ & $+(1 / 2)$ \\
1D2 & $+(3 / 3)$ & $+(1 / 1)$ \\
$4 \mathrm{E} 2$ & $+(3 / 3)$ & $+(1 / 1)$ \\
$3 \mathrm{D} 11$ & $\pm(3 / 6)$ & $0(0 / 2)$ \\
$1 \mathrm{H} 8$ & $\pm(6 / 8)$ & $\pm(3 / 4)$ \\
1D3 & $\pm(2 / 4)$ & $\pm(3 / 4)$ \\
1D11 & $\pm(3 / 6)$ & $\mathrm{NT}$ \\
1C4 & $-(0 / 1)$ & $\mathrm{NT}$ \\
$2 \mathrm{G} 10$ & $-(0 / 1)$ & $\mathrm{NT}$ \\
1B3 & $-(0 / 2)$ & $-(0 / 3)$ \\
& & \\
\hline
\end{tabular}

* No. of cultures showing a positive response/total No. of individuals tested. ${ }^{\ddagger} \mathrm{T}$ cells derived by limiting dilution from an expanding psoriatic lesion. Supernatants were generated by activation of clones on immobilized anti-CD3 and fibronectin. + , consistently increased clonal growth by the $\mathrm{T}$ cell supernatant over the control media (AIM V) from succesive subjects; \pm , supernatants induced both a positive response and no response in successive cultures; 0 , no effect of the supernatant on clonal growth; -, inhibition of keratinocyte clonal growth; NT, not tested. effect on at least $50 \%$ of psoriatic donors. (Table I), suggesting that growth-promoting clones are common among $\mathrm{T}$ cells undergoing intralesional activation, although preferential selection in vitro under low $\mathrm{IL}-2$ concentrations for a reason other than high affinity IL-2 receptor expression shortly after activation is conceivably possible.

Quantitation of $\beta 1$ integrin ${ }^{+} \mathrm{K} 1 / \mathrm{K} \mathrm{O}^{-}$stem cell-containing epidermal cell subset transition to cell cycle reveals that growth of psoriatic uninvolved, but not normal stem cells can be stimulated by psoriatic lesional $T$ cell supernatants. Since cells were cultured for $2 \mathrm{wk}$ and restimulated with $\mathrm{T}$ cell supernatants every third day in the clonal growth assay, the observed growth stimulation of $\mathrm{T}$ cell lymphokines can be attributed to either growth stimulation of the $\beta 1$ integrin $^{+} \mathrm{K} 1 /$ $\mathrm{K}_{10}{ }^{-}$subset or growth stimulation of the $\beta 1$ integrin $^{+} \mathrm{K} 1 /$ $\mathrm{K} 0^{+}$subset, which is committed to terminal differentiation, but which undergoes transient amplification. Because the primary hyperproliferative subset in lesional psoriatic epidermis is the stem cell population, we tested whether the colony growth stimulatory $\mathrm{T}$ cell supernatant (4F4) could stimulate the growth of $\beta 1$ integrin ${ }^{\text {bright }} \mathrm{K} 1 / \mathrm{K}^{-} 0^{-}$cells early (in the first $72 \mathrm{~h}$ of culture) during primary ex vivo culture.

Psoriatic uninvolved epidermal cells were obtained from seven patients and, in all but one case, lesional $\mathrm{T}$ cell (clone 4F4) supernatant induced substantially higher numbers of $\beta 1$ integrin ${ }^{\text {bright }}$ cells to appear after $72 \mathrm{~h}$ of primary culture relative to cultures of uninvolved epidermal cells plated in control media. The percent $\beta 1$ integrin $^{\text {bright }}$ cells rose from $3.2 \pm 0.7$ in control media cultures to $9.1 \pm 2.2$ in lesional $\mathrm{T}$ cell supernatantstimulated cultures (Fig. 3, $P=0.009$ ). T cell clone 4F1, another clone which was stimulatory in the clonal growth assay, also induced stem cell growth in primary culture $(10.3 \pm 0.6 \%$ $\beta 1$ integrin $^{\text {bright }}$ cells in $4 \mathrm{~F} 1$ cultures and $4.7 \pm 0.2 \% \beta 1$ inte- 


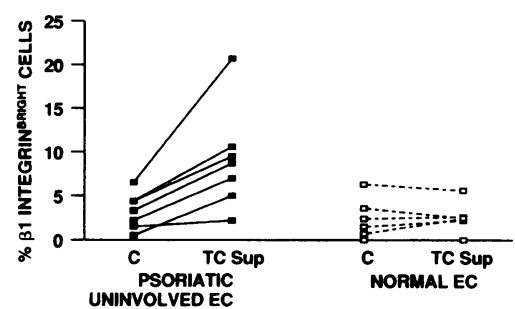

Figure 3. Psoriatic uninvolved 72 -h cultures show significantly higher numbers of $\beta 1$ integrinbright cells in the presence of psoriatic $\mathrm{T}$ cell supernatant. Cloned $\mathrm{T}$ cell supernatants were added as in Fig. 2 to uninvolved psoriatic $(n=7, P$

$=0.009)$ or normal epidermal cells $(n=6, P=0.76)$ plated in $\mathrm{KBM} \pm 1 \%$ FBS (TC Sup). Control cultures (C) were treated with 1:100 dilution of AIM V medium. After $72 \mathrm{~h}$, cells were stained with anti- $\beta 1$ integrin and propidium iodide and analyzed by flow cytometry.

grin $^{\text {bright }}$ cells in control cultures, $n=2$ ).

Although conditions of $\mathrm{T}$ cell activation in the skin can result in epidermal hyperplasia in nonpsoriatic individuals (i.e., chronic dermatitis or tuberculoid leprosy [38]), the hyperplasia in psoriatic subjects is more intense and sustained, suggesting a hyperresponsive state. We therefore compared the hyperplastic response of psoriatic uninvolved keratinocyte stem cells to epidermal stem cells from normals $(n=6)$. In contrast to the increased stem cell numbers appearing in cultures of psoriatic uninvolved cells, we could not detect lesional $\mathrm{T}$ cell induction of increased numbers of $\beta 1$ integrin $^{\text {bright }}$ cell population in epidermal cell cultures from normal individuals (Fig. $3, P=0.76$ ). Increased numbers of $\beta 1$ integrin $^{\text {bright }}$ cells in cultures provided $\mathrm{T}$ cell lymphokines is likely due to proliferation of this subset, but could also represent preferential nonproliferative survival in the treated culture. We therefore asked if increased cell division among these cells was responsible for the preferential increase in numbers of $\beta 1$ integrin $^{\text {bright }}$ cells. Quantitation of the DNA content of $\beta 1$ integrin ${ }^{\text {bright }}$ cells revealed that the proportion of $\beta 1$ integrin $^{\text {bright }}$ cells that were hyperdiploid, that is, in $\mathrm{S} / \mathrm{G}_{2} /$ $M$ phase of the cell cycle, was indeed significantly enhanced by the addition of activated $T$ cell supernatant (Fig. 4, $P$ $=0.01)$. The percentage of $\beta 1$ integrin $^{\text {bright }}$ cells in $\mathrm{S} / \mathrm{G}_{2} / \mathrm{M}$ rose from $1.08 \pm 0.2 \%$ in control media cultures to $2.3 \pm 0.5 \%$ in lesional $\mathrm{T}$ cell-stimulated cultures (Fig. 4). Thus, $\mathrm{T}$ cell lymphokines increase cycling among the culture-initiating keratinocytes of stem cell phenotype (1). Furthermore, in keeping with the cell number data, and in contrast to psoriasis, epidermal cell cultures from normals did not exhibit an increase in the $S$ / $\mathrm{G}_{2} / \mathrm{M}$ phase $\beta 1$ integrin ${ }^{\text {bright }}$ population in response to $\mathrm{T}$ cell stimulation (Fig. $4, P=0.66$ ).

These data provide the first evidence that elements of the immune system, in particular, lesional psoriatic $\mathrm{T}$ cells, can directly upregulate the growth of keratinocyte stem cells. Of

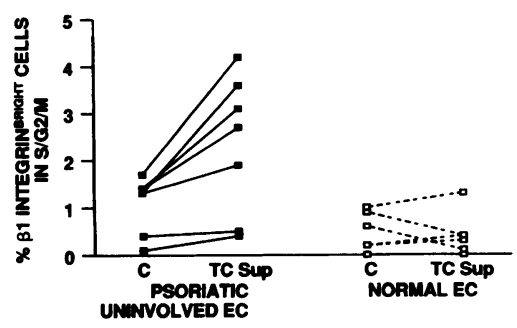

Figure 4. Psoriatic T cell supernatant induces the proliferation of $\beta 1$ integrin ${ }^{\text {bright }}$ cells in psoriatic uninvolved epidermal cell cultures. Psoriatic uninvolved $(n=7, P=$ $0.01)$ and normal $(n=6$, $P=0.66)$ epidermal cells were treated as described in Fig. 3. Cycling $\beta 1$ integrin $^{\text {bright }}$ cells were identified based on DNA content determined by propidium iodide staining.
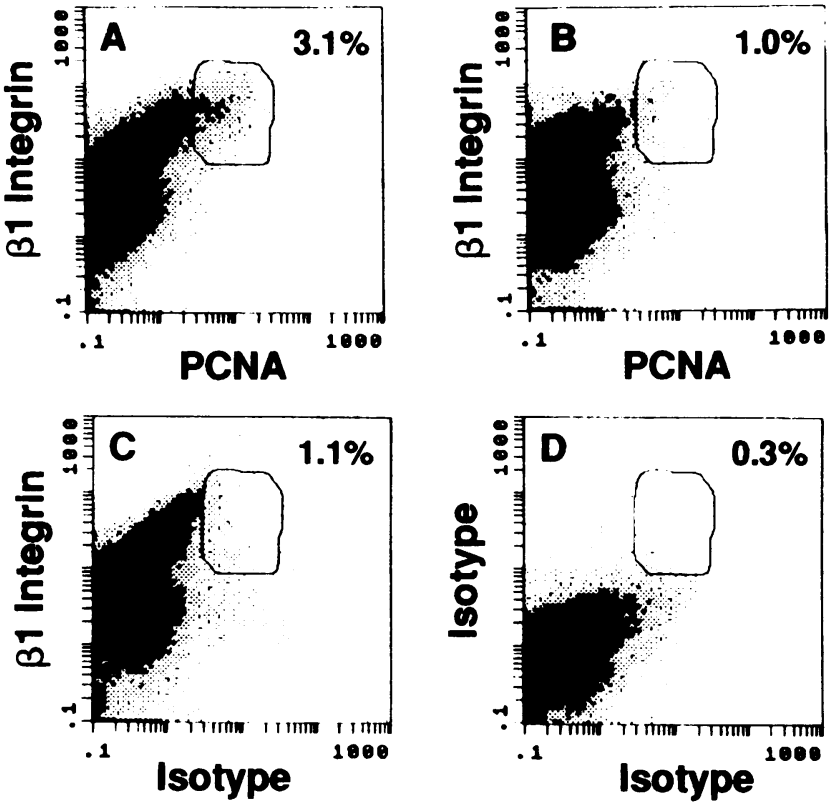

Figure 5. Cell cycle entry (PCNA expression) precedes acquisition of $\beta 1$ integrin $^{\text {bright }}$ phenotype; acceleration by growth stimulatory $\mathrm{T}$ cells. Epidermal cells from psoriatic uninvolved skin were cultured in KBM $+1 \%$ FBS either in the presence of a growth stimulatory supernatant of an activated T cell clone (4F4) $(A)$ or in control media (AIM V) $(B)$. Cells were harvested after $48 \mathrm{~h}$ then costained with anti- $\beta 1$ integrin and anti-PCNA and analyzed by flow cytometry. After substraction of cells with nonspecific fluorescence detected by isotype staining (circle, C) a small but distinct PCNA ${ }^{+}$cell population is apparent in the T cell supernatant containing culture (circle, $A, 2 \%$ after subtraction) whereas there is no $\mathrm{PCNA}^{+}$cell population at this time in the control culture (circle, $B, 0 \%$ after subtraction). $\beta 1$ integrin positivity is determined as $y$ axis fluorescence, relative to $D$.

additional importance is that psoriatic keratinocyte stem cells appear to be in an altered state relative to normals, as they are hyperresponsive to the growth promoting effect of $\mathrm{T}$ cell lymphokines.

$T$ cell induction of increased cells with bright $\beta 1$ integrin expression is preceded by the appearance of $\beta 1$ integrin ${ }^{+}$cells expressing the early $G_{1}$ marker, PCNA. Increased $\beta 1$ integrin bright -proliferating cells could be due to enhanced $\beta 1$ integrin expression without increased cycling, to accelerated cycling of the small percentage of stem cells already in cycle in vivo $(4.5 \%)(4)$ or to a recruitment of previously quiescent $\left(G_{0}\right)$ stem cells into cell cycle. Because DNA content can not detect $G_{1}$ entry (the cells are still diploid), we used another marker of cell cycle entry into $G_{1}$. PCNA is an auxiliary DNA polymerase molecule which appears early in $\mathrm{G}_{1}$. It becomes somewhat more abundant during $S$ and then declines during $G_{2} / M(39,40)$. Psoriatic uninvolved cultured epidermal cells were costained with anti- $\beta 1$ integrin and anti-PCNA antibodies 48 and $72 \mathrm{~h}$ after initiation of the cultures (Figs. 5 and 6). Cells were grown in media either supplemented with a growth stimulatory $\mathrm{T}$ cell supernatant (4F4) or AIM V control media. After $48 \mathrm{~h}$ of culture, none of the cultures contained $\beta 1$ integrin $^{\text {bright }}$ cells, as evidenced by the single homogenous population of $\beta 1$ integrin + cells (circles, Fig. $5 D$ vs $A-C$ ). Despite the lack of $\beta 1$ integrin $^{\text {bright }}$ cells, we were able to detect an increase in PCNA ${ }^{+}$ cells in the T cell-treated culture at $48 \mathrm{~h}$. In cultures containing 

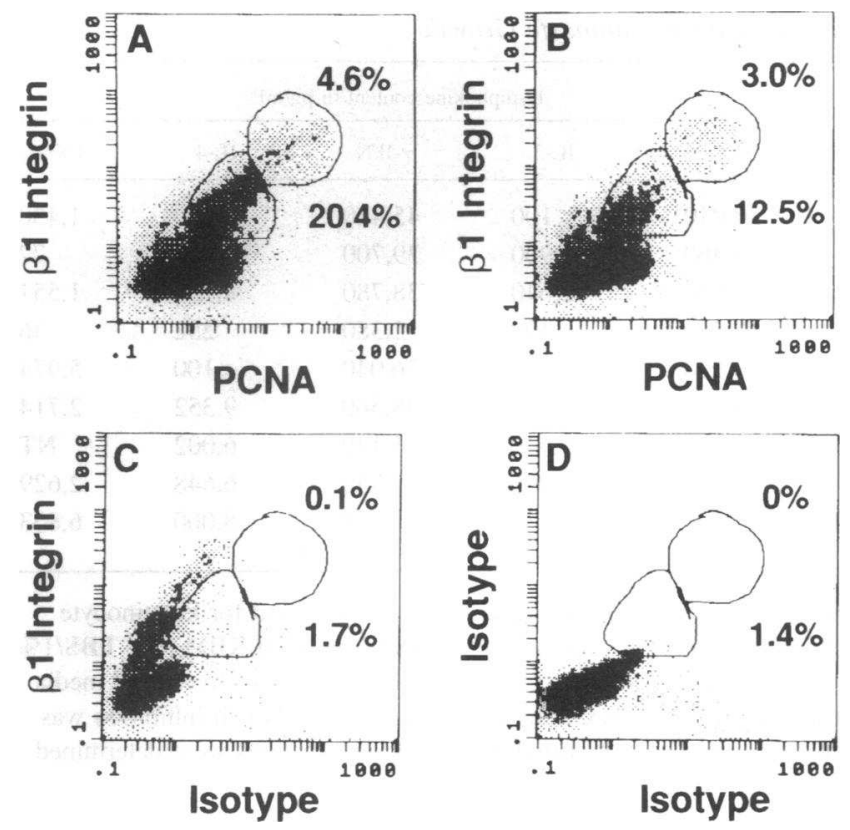

Figure 6. Accelerated recruitment and proliferation of two subsets of $\beta 1$ integrin ${ }^{+} \mathrm{PCNA}^{+}$cells by $\mathrm{T}$ cells. Psoriatic uninvolved epidermal cells were cultured for $72 \mathrm{~h}$ and costained with anti- $\beta 1$ integrin and anti-PCNA. At this time, two populations of $\beta 1$ integrin $^{+}$cells are now apparent, ( $y$ axis fluorescence $>1.3[D$ vs. $A-C]$ defining minimum positivity). In addition to the $\beta 1$ integrin ${ }^{+}$population which has (lower circle) become almost entirely $\mathrm{PCNA}^{+}$at $72 \mathrm{~h}(A$ and $B$ vs. $C)$ as compared to $\leq 2 \%$ at $48 \mathrm{~h}$, there is now a substantial $\beta 1$ integrin $^{\text {bright }}$ population which is entirely PCNA ${ }^{\text {bright }}(A, B$ vs. $C$, upper circles $)$. T cells accelerated the appearance of both populations ( $A$ vs. $B$ substracted by $C$ ).

the $\mathrm{T}$ cell supernatant, $2.0 \%$ of total epidermal cells were PCNA $^{+}$(Fig. $5 A$, encircled cells minus Fig. $5 C$ encircled cells) as opposed to $0 \% \mathrm{PCNA}^{+} \beta 1$ integrin ${ }^{+}$keratinocytes in culture containing control media (Fig. $5 B$ ). The lack of PCNA ${ }^{+}$ cells over background fluorescence in control media-containing cultures indicates that initial keratinocyte colony formation in vitro depends entirely on quiescent, $\mathrm{PCNA}^{-}$cell recruitment into cell cycle. Even though bright $\beta 1$ integrin expression was not yet detectable, all PCNA ${ }^{+}$cells in the T cell-treated culture were within the $\beta 1$ integrin ${ }^{+}$population. The $\mathrm{PCNA}^{+}$cells tended to arise within the cells expressing somewhat higher amounts of $\beta 1$ integrin, however (Fig. $5 A$ ), consistent with the concept that these cells arise from the in vivo stem cell population, which exhibits slightly higher $\beta 1$ integrin than neighboring transient amplifying cells $(41,42)$.

After $72 \mathrm{~h}$, two populations of $\beta 1$ integrin $^{+}$cells could be detected, one bright and the other dim in intensity (Fig. 6, $A$ and $B$ upper and lower encircled areas; vs. Fig. $6 D$ ). (The reason that $\beta 1$ integrin $^{\text {bright }}$ cells in the 72 -h harvest have a $\beta 1$ fluorescence intensity in the third logarithmic decade,.and the single population of $\beta 1$ integrin ${ }^{\text {dim }}$ cells in the 48 -h culture also have $\beta 1$ fluorescence intensity in the third decade, is that the data were acquired on two sequential days, and there was nonidentical voltage amplification during acquisition.) Comparison of cells stained with anti- $\beta 1$ integrin plus isotype (Fig. $6 C$ ) with 72 -h cells stained with both anti- $\beta 1$ integrin and antiPCNA (Fig. 6, $A$ and $B$ ) revealed that virtually all $\beta 1$ integrin $^{+}$
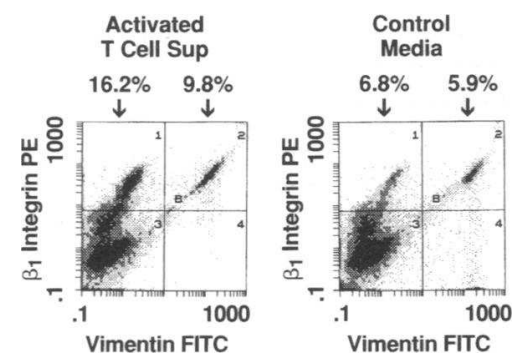

Figure 7. Lesional psoriatic $\mathrm{T}$ cell lymphokines preferentially enhance keratinocyte growth. Psoriatic uninvolved epidermal cells were cultured as described in Fig. 3. After $72 \mathrm{~h}$ cells were collected and costained with anti- $\beta 1$ integrin $(\mathrm{PE})$ and anti-vimentin (FITC). Bright $\beta 1$ integrin expression can be detected on vimentin ${ }^{+}$ cells (quadrants 2 ) identifying melanocytes and Langerhans cells in the cultures. Keratinocyte stem cells are vimentin ${ }^{-} \beta 1$ integrin ${ }^{\text {bright }}$ (quadrants 1 ).

cells were $\mathrm{PCNA}^{+}$, and the high PCNA expressing cells were all now $\beta 1$ integrin $^{\text {bright }}$ (Fig. 6, $A$ and $B$ upper circles). Increased cell numbers of the $\mathrm{PCNA}^{+} \beta 1$ integrin ${ }^{+}$and $\mathrm{PCNA}^{\text {bright }}$ $\beta 1$ integrin $^{\text {bright }}$ populations were detectable in $\mathrm{T}$ cell supernatant-treated (Fig. $6 \mathrm{~A}$ ) relative to control media-containing cultures (Fig. $6 \mathrm{~B}$ ). The total $\mathrm{PCNA}^{+}$population comprised $23.2 \%$ vs. $13.7 \%$ of 72 -h cultured epidermal cells, respectively, and the $\beta 1$ integrin $^{\text {bright }}$ and PCNA ${ }^{\text {bright }}$ subset comprised $4.5 \%$ of the T cell-stimulated culture as compared to $2.9 \%$ of the control media-treated culture (Fig. $6, A$ vs. $B$ minus $C$ ). We have measured $\mathrm{PCNA}^{+}$cells parallel with $\beta 1$ integrin ${ }^{\text {bright }}$ cells in two other experiments in 72-h cultures and detected similar differences in the numbers of $\mathrm{PCNA}^{+}$and $\beta 1$ integrin ${ }^{\text {bright }}$ cells between $T$ cell supernatants-treated cultures and control cultures (data not shown).

These data suggest that the growth-promoting effect of the lesional $\mathrm{T}$ cell supernatant is due to accelerated recruitment of $\beta 1$ integrin $^{+}$stem cells into $G_{1}$ and that cell cycle entry (PCNA expression) precedes the marked upregulation of $\beta 1$ integrin which occurs among the clonogenic stem cells as they establish the culture. The very bright PCNA expression among the $\beta 1$ integrin $^{\text {bright }}$ cells likely indicates a build-up of PCNA protein during repeated, relatively rapid rounds of cell cycle (35), whereas the $\beta 1^{+} \mathrm{PCNA}^{+}$population's expansion may represent further stem cell recruitment.

Lesional psoriatic $T$ cell lymphokines preferentially enhance $\beta 1$ integrin ${ }^{+}$keratinocyte growth over $\beta 1$ integrin $^{+}$melanocytes and Langerhans cells. Epidermal cell cultures in KBM $+1 \%$ FBS media consist mainly ( $>95 \%$ ) of keratinocytes; however, it is possible that melanocytes and Langerhans cells may proliferate in cultures stimulated by $\mathrm{T}$ cells. Like the keratinocyte stem cell-containing population, melanocytes and Langerhans cells are also $\beta 1$ integrin $^{+} \mathrm{K} 1 / \mathrm{K}^{-} 0^{-}$in in vivo epidermis $(4,43,44)$. Therefore it was important to determine whether melanocytes or Langerhans cells are present in the $\beta 1$ integrin ${ }^{\text {bright }} \mathrm{K} 1 / \mathrm{K} 10^{-}$population in the short-term cultures and to quantitate their contribution to the enhanced proliferation of the $\beta 1$ integrin $^{\text {bright }} \mathrm{K} 1 / \mathrm{K}_{10}{ }^{-}$population after exposure to lesional psoriatic $\mathrm{T}$ cell supernatant. This was accomplished by costaining short-term cultured psoriatic uninvolved epidermal cells with anti- $\beta 1$ integrin plus anti-vimentin monoclonal antibodies. (Anti-vimentin stains Langerhans cells, melanocytes, and infiltrating lymphoid cells in the epidermis [44].)

As expected, after $72 \mathrm{~h}$, vimentin ${ }^{+}$cells were found in the culture; moreover, almost all exhibited $\beta 1$ integrin ${ }^{\text {bright }}$ expression (Fig. 7, quadrants 2 ). The psoriatic $\mathrm{T}$ cell supernatant- 
Table II. Lymphokine Profile of Lesional Psoriatic T Cell Subsets: Correlation with Keratinocyte Growth

\begin{tabular}{|c|c|c|c|c|c|c|c|c|c|}
\hline \multirow[b]{2}{*}{ Cloned T cells* } & \multicolumn{3}{|c|}{$\mathrm{T}$ cell phenotype ${ }^{\ddagger}$} & \multirow[b]{2}{*}{ KC clonal growth ${ }^{8}$} & \multicolumn{5}{|c|}{ Lymphokine content in $\mathrm{pg} / \mathrm{ml}^{l l}$} \\
\hline & $\mathrm{CD} 4$ & CD8 & CD3 & & GM-CSF & IL-3 & $\gamma$-IFN & IL-4 & TNF- $\alpha$ \\
\hline $1 \mathrm{C} 11$ & + & - & + & + & 10,040 & $<100$ & 45,420 & $<100$ & 1,438 \\
\hline $4 \mathrm{~F} 1$ & + & - & + & + & 10,360 & 2,900 & 39,700 & 15,364 & 77 \\
\hline $4 \mathrm{~F} 4$ & + & - & + & + & 10,920 & 2,640 & 38,780 & 8,181 & 1,551 \\
\hline $3 \mathrm{D} 11$ & + & - & + & \pm & 10,540 & $<100$ & 32,380 & 252 & 36 \\
\hline $1 \mathrm{H} 8$ & + & - & + & \pm & 10,300 & $<100$ & 36,040 & $<100$ & 5,974 \\
\hline $1 \mathrm{D} 3$ & + & - & + & \pm & 10,260 & 9,220 & 38,560 & 9,352 & 2,714 \\
\hline $1 \mathrm{C} 4$ & NT & NT & NT & - & 9,100 & 33,940 & 51,140 & 6,002 & NT \\
\hline $1 \mathrm{~B} 3$ & - & + & $+(\alpha, \beta)$ & - & $<100$ & 34,060 & 39,940 & 6,648 & 2,629 \\
\hline $2 \mathrm{G} 10$ & - & + & $+(\alpha, \beta)$ & - & 9,340 & 32,780 & NT & 8,000 & 6,853 \\
\hline
\end{tabular}

* $\mathrm{T}$ cells expanded in low dose IL-2 from untreated expanding psoriatic papule were cloned by limiting dilution and screened for keratinocyte clonal growth regulatory activity. ${ }^{\ddagger} \mathrm{T}$ cells were phenotyped by dual color flow cytometry. ${ }^{\S}$ Keratinocyte clonal growth in KBM $+1 \% \mathrm{FBS} / 1 \%$ Aim V media was assessed after addition of $48 \mathrm{~h}$ supernatants derived from anti-CD3 + fibronectin-stimulated T-cells. Relative to Aim V media control, growth promotion was scored as + if repeated experiments demonstrated an increase in colony density and size. Growth inhibition was scored as - if reduced colony density and size was observed. "Lymphokine levels in the 48-h stimulated T cell supernatants were determined by ELISA. NT, not tested.

treated culture (Fig. 7) contained 9.8\% $\beta 1$ integrin $^{+ \text {(bright) }}$ vimentin $^{+}$cells, whereas the control culture contained $5.9 \%$ $\beta 1$ integrin $^{\text {bright }}$ vimentin $^{+}$cells, indicating that melanocyte and Langerhans cell survival or growth can also be positively influenced by the lesional psoriatic $\mathrm{T}$ cell lymphokines. More importantly, however, T cell-stimulated psoriatic uninvolved epidermal cells, free of contaminating vimentin ${ }^{+}$Langerhans cells, and melanocytes, contained $16.2 \% \beta 1$ integrin $^{\text {bright }}$ vimentin $^{-}$ keratinocyte stem cells, whereas the control media culture contained only $6.8 \% \beta 1$ integrin $^{\text {bright }}$ vimentin $^{-}$keratinocytes. This confirms that the growth stimulation of psoriatic lesional $\mathrm{T}$ cell lymphokines on $\beta 1$ integrin $^{+} \mathrm{K} 1 / \mathrm{K}_{10} 0^{-}$epidermal cells is indeed an effect on keratinocytes, and that, in fact, $\mathrm{T}$ cell stimulation is most potent for keratinocytes.

Heterogeneity of cloned lesional psoriatic $T$ cells in regard to keratinocyte clonal growth correlates with CD4 and CD8 expression of the $T$ cells as well as differential lymphokine production. Our finding that certain cloned lesional psoriatic $\mathrm{T}$ cells induced enhanced keratinocyte clonal growth, whereas others inhibited growth provided an opportunity to examine whether distinct "growth stimulatory" lymphokine profiles could be identified. To answer this question we have measured, by ELISA, the IL-3, IL-4, GM-CSF, TNF- $\alpha$, and gamma-interferon levels in the activated lesional psoriatic $\mathrm{T}$ cell supernatants. High GM-CSF (10-11 ng/ml) and ' $\gamma$-IFN (38-51 ng/ $\mathrm{ml}$ ) levels were characteristic of the growth stimulatory (upper group, Table II), and some of the growth inhibitory (lower group, Table II) $\mathrm{T}$ cell supernatants. Growth inhibition correlated with high IL-3 (32-34 ng/ml) and moderate TNF- $\alpha$ (2.6$6.8 \mathrm{ng} / \mathrm{ml}$ ) levels, whereas growth stimulatory supernatants contained $<3 \mathrm{ng} / \mathrm{ml} \mathrm{IL-3}$ and $<1.5 \mathrm{ng} / \mathrm{ml}$ TNF- $\alpha$. No obvious connection was found between cell growth and IL-4 levels; with most of the T cells producing substantial levels of both $\gamma$-IFN and IL-4, only three exhibiting a type I lymphokine profile (high $\gamma$-IFN, absent or very low IL-4), and none exhibiting a type II profile (low $\gamma$-IFN, high IL-4) (Table II). Thus, enhanced keratinocyte growth can not be obviously associated with high levels of any of the tested lymphokines. However, phenotypic analysis of the $\mathrm{T}$ cells revealed that growth stimula- tory lymphokine production was exclusively mediated by $\mathrm{CD} 4^{+}$ $\mathrm{T}$ cells, whereas $\mathrm{T}$ cells producing the inhibitory supernatants that were stained were composed of $\mathrm{CD}^{-}{ }^{-} \mathrm{CD} 3^{+} \mathrm{T}$ cells that contained $\mathrm{CD}^{+}{ }^{+}$cells and $\mathrm{CD} 8^{-}$cells, but which all expressed $\alpha, \beta$ T cell receptor (TCR) and not $\gamma, \delta$ TCR (Table II).

Lesional $T$ cell stimulation of psoriatic keratinocyte stem cell hyperproliferation is multifactorial, $\gamma-I F N$ appears to be a critical component for growth stimulation, but requires the presence of other growth factors. To determine which lymphokines present in the activated lesional $\mathrm{T}$ cell supernatants are critical for the observed enhancement of keratinocyte stem cell growth by the activated lesional $\mathrm{T}$ cell supernatants, we used neutralizing antibodies against IL-3, GM-CSF, and $\gamma$-IFN. Each antibody, or its isotype control, was added to the T cell supernatant to block the effect of these individual lymphokines in the 72-h short-term psoriatic uninvolved epidermal cell culture assay. The neutralizing antibody concentrations were calculated to achieve a 100 -fold excess of neutralizing activity based upon the known amounts of lymphokines in the supernatants and the neutralizing activity of each antibody. In each of four experiments anti- $\gamma$-IFN neutralization resulted in inhibition of keratinocyte growth, with a $39 \pm 7.7 \%$ inhibition of $\beta 1$ integrin $^{\text {bright }}$ cell numbers and a $34 \pm 6.3 \%$ inhibition in the numbers of $S /$ $\mathrm{G}_{2} / \mathrm{M}$ phase $\beta 1$ integrin $^{\text {bright }}$ cells, relative to isotype control cultures (Fig. 8). Addition of anti- $\gamma$-IFN to the cultures did not influence the number and proliferation of vimentin ${ }^{+}$cells, indicating that keratinocytes are a specific target of growth stimulation by $\gamma$-IFN (data not shown).

No consistent growth inhibition was observed upon addition of either anti-GM-CSF or anti-IL-3 (Fig. 8). Addition of the neutralizing anti-GM-CSF and anti-IL-3 to the epidermal cell cultures without the growth-promoting supernatant 4F4 also did not influence keratinocyte stem cell growth, suggesting that autocrine production of these lymphokines was not responsible for growth regulation. Addition of neutralizing antibody against TNF- $\alpha$ also did not affect keratinocyte stem cell growth (data not shown).

To test the possibility that $\gamma$-IFN alone could be responsible for the growth stimulatory effect on psoriatic keratinocyte stem 


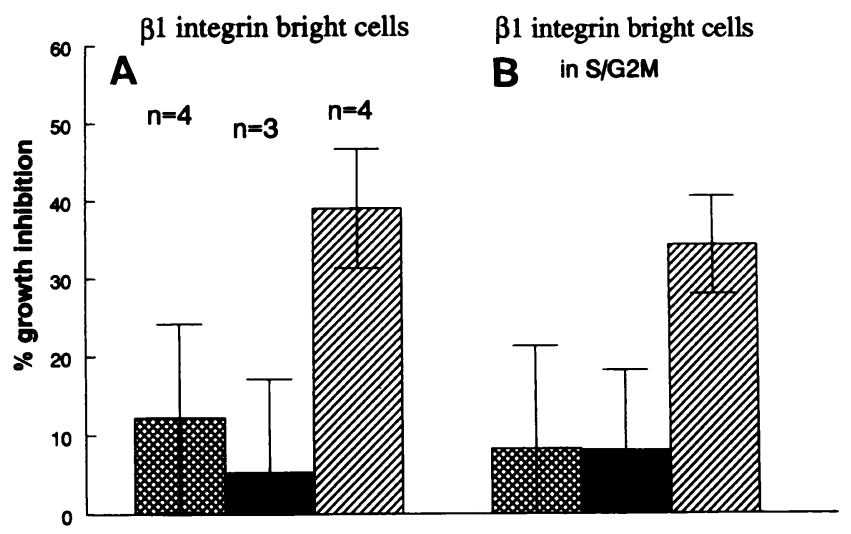

\section{anti-IL-3 anti-GM-CSF WIIS anti- $\gamma$ IFN}

Figure 8. Identification of specific lymphokines responsible for psoriatic uninvolved epidermal stem cell growth activation. Neutralizing antibodies against anti-IL-3, anti-GM-CSF, anti- $\gamma$ IFN, and appropriate isotype controls were added separately to psoriatic uninvolved epidermal cell cultures before addition of a growth-promoting $\mathrm{T}$ cell supernatant (4F4). After $72 \mathrm{~h}$ cells were harvested, fixed, stained with anti- $\beta 1$ integrin plus $\mathrm{PI}$ and anti-vimentin plus PI, and analyzed by flow cytometry. Epidermal stem cell growth was measured either by the number of $\beta 1$ integrin ${ }^{\text {bright }}$ cells $(A)$ or the number of $\beta 1$ integrin $^{\text {bright }}$ cells in $\mathrm{S} / \mathrm{G}_{2} / \mathrm{M}$ phase $(B)$ after $72 \mathrm{~h}$. Control cultures containing species and isotype matched immunoglobulins were considered to represent $100 \%$ growth.

cells, we cultured psoriatic uninvolved epidermal cells in KBM $+1 \%$ FBS supplemented with human recombinant $\gamma$-IFN at 10 and $100 \mathrm{U} / \mathrm{ml}$. (These concentrations were chosen based on the specific activity/mg protein of this recombinant $\gamma$-IFN. The ELISA-determined $\gamma$-IFN concentrations in the T cell supernatants fall within this $10-100-\mathrm{U} / \mathrm{ml}$ range.) We found that, in each instance, cell growth in the cultures was suppressed (39\% and $44 \pm 19 \%$ at 10 and $100 \mathrm{U} / \mathrm{ml}$, respectively). Taken together with the above data that $\gamma$-IFN is critical for growth promotion, the growth inhibitory effect of the isolated $\gamma$-IFN indicates that $\gamma$-IFN requires the presence of additional factors (i.e., GMCSF, IL-3, or others) simultaneously produced by activated lesional $\mathrm{T}$ cells in order to stimulate psoriatic keratinocyte stem cell growth.

\section{Discussion}

To determine whether the behavior of human keratinocyte stem cells could be studied ex vivo in a state as close as possible to their in vivo state (before multiple in vitro passage modulation), we analyzed primary ex vivo epidermal cell cultures and tracked the numbers and cell cycle status of cells of stem cell phenotype by multiparameter flow cytometry. In a time course study, we demonstrated that in this culture system $(\mathrm{KBM}+1 \%$ FBS media), keratinocytes responsible for initial colony formation are of the $\beta 1$ integrin $^{+} \mathrm{K} 1 / \mathrm{K}_{10}{ }^{-} \mathrm{PCNA}^{-}$stem cell phenotype. Thus, at the time when small colonies, (5-6 cells of monolayered keratinocytes) were seen in the culture, all the cells were $\mathrm{K} 1 / \mathrm{K} 10^{-}$. Parallel to accelerated proliferation, the $\beta 1$ integrin expression of these clonogenic cells became very bright in vitro. Later, as the colonies enlarge, differentiation occurred (K1/ $\mathrm{K} 10$ expression appeared). In confluent cultures the majority,

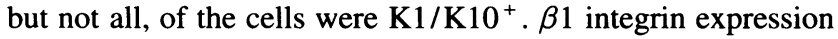

remained, however, the intensity diminished somewhat as the proliferation of the cells slowed down.

The $\beta 1$ integrin $^{\text {bright }} \mathrm{K} 1 / \mathrm{K}^{-} 0^{-}$clonogenic cell population was detectable as early as $72 \mathrm{~h}$ after initiation of epidermal cell cultures. It has been shown recently that in multiply passaged neonatal foreskin keratinocyte cultures, cells with bright $\beta 1$ integrin expression were the most efficient cells for colony formation (1). Because such cells have survived multiple proliferative activations (2-12 passages), yet could still regain proliferative capacity without showing signs of differentiation, they most likely represent the progeny of the in vivo stem cell population (1).

In vivo, under steady state conditions, epidermal stem cells are believed to divide infrequently and to have a long cell cycle time (45). However, when placed into culture, label-retaining cells thought to be epidermal stem cells are known to be actively cycling and clonogenic $(35,46)$. Congruent with these prior findings, the majority of epidermal stem cells are in a quiescent cell cycle state in in vivo normal epidermis (diploid DNA content, $\mathrm{PCNA}^{-}$) (4) and some are recruited spontaneously from quiescent state into cell cycle in the culture between 48 and 72 $\mathrm{h}\left(\mathrm{PCNA}^{+}\right)$. Thus, clonal growth in the early primary culture depends on the rate of stem cells leaving cell quiescence $\left(\mathrm{G}_{0}-\right.$ $\mathrm{G}_{1}$ transition ).

After the initial death of existing differentiated cells (K1/ $\mathrm{K} 10^{+}$, the stem cell-containing cell population ( $\beta 1$ integrin $^{+}$ $\mathrm{K} 1 / \mathrm{K}^{-} 0^{-}$) expanded through proliferation, but a substantial fraction simultaneously and asymmetrically generated $\mathrm{K} 1 /$ $\mathrm{K}_{10}{ }^{+}$cells. The $\beta 1$ integrin ${ }^{+} \mathrm{K} 1 / \mathrm{K} 10^{+}$phenotype is characteristic of the population in in vivo epidermis which has committed to differentiation but undergoes transient amplification before terminal differentiation. Thus, in confluent primary culture, keratinocytes are composed of two basic proliferative populations: $\beta 1$ integrin ${ }^{+} \mathrm{K} 1 /{\mathrm{K} 10^{-}}^{-}$(stem cells) and $\beta 1$ integrin ${ }^{+} \mathrm{K} 1 / \mathrm{K}_{10}{ }^{+}$ (transient amplifying) cells.

Using the above monoclonal antibody markers in combination with cell cycle analysis, we have previously found that the primary hyperproliferative cell subset in lesional psoriatic epidermis was the normally slow cycling $\beta 1$ integrin ${ }^{+} \mathrm{K} 1 /$ $\mathrm{K}_{10}{ }^{-}$subset. The ability to model events leading to stem cell hyperplasia in psoriasis is critically important in understanding stem cell homeostasis and is relevant not only to psoriasis but to epithelial cancer and immune regulation of tissue proliferation as well. By tracking the behavior of the $\beta 1$ integrin ${ }^{+} \mathrm{K} 1 /$ $\mathrm{K}_{10}{ }^{-}$stem cells after exposure to $\mathrm{T}$ cell products, we provide definitive evidence for a direct link, via secreted lymphokines, between lesional $\mathrm{T}$ cells and the relevant target cell in psoriasis, the epidermal proliferative compartment keratinocytic stem cell $\left(\beta 1\right.$ integrin $^{+}, \mathrm{K} 1 / \mathrm{K}^{-} 0^{-}$, vimentin $\left.^{-}\right)$. That the growth activation was actually occurring in the keratinocyte stem cell population was confirmed by vimentin staining which identified Langerhans cells and melanocytes in the cultures.

We demonstrated, using the supernatants of anti-CD3 plus fibronectin-activated $\mathrm{T}$ cells cloned from an expanding psoriatic lesion, differential growth regulation of clonal keratinocyte growth in vitro. Both normal and psoriatic uninvolved keratinocyte clonal growth stimulation could be linked to a group of $\mathrm{CD}^{+}{ }^{+} \mathrm{T}$ cells whose supernatants contained relatively high levels of GM-CSF and $\gamma$-IFN, and moderate to low levels of IL3 and TNF- $\alpha$. Growth stimulatory T cell clones could not be exclusively assigned to a type I lymphokine profile (28), because at least two clones produced substantial IL-4 as well as 
$\gamma$-IFN (Table II). Interestingly, we observed growth inhibition by cloned $\mathrm{T}$ cells containing $\mathrm{CD} 8^{+} \mathrm{CD} 3^{+} \mathrm{CD} 4^{-} \mathrm{TCR} \alpha / \beta^{+}$ cells which demonstrated much higher IL-3 and somewhat higher TNF- $\alpha$ production. We do not yet know whether high IL-3 and/or moderate TNF- $\alpha$ can inhibit growth directly or whether it can enhance differentiation with resultant reduced clonal growth. The reason for the normal keratinocyte response to growth stimulatory $T$ cell in the long-term clonal growth assays, but not the short-term stem cell assay is not entirely clear, but may relate to the more complex composition of proliferative cells in the more mature colonies of the long-term assay. Measurement of growth in the latter assay includes the growth of both stem and transiently amplifying keratinocytes, as well as melanocytes. Thus, because it is not possible to identify the actual target cell of action, it is difficult to interpret our longterm clonal growth assay and other proliferative assays involving cultured keratinocytes treated with $\mathrm{T}$ cell supernatants (30) or recombinant lymphokines (47-49).

Although both IL-3 and GM-CSF seem to be growth-promoting factors for keratinocytes in vivo (50-52) as well as in vitro on passaged cells (47), our neutralization experiments in the short-term primary culture model suggest that $\gamma$-IFN, and not GM-CSF or IL-3, is a potent stimulatory cofactor in psoriatic uninvolved keratinocyte stem cell proliferation. $\gamma$-IFN has been reported to inhibit normal, and to a lesser degree, psoriatic, epidermal cell growth in vitro in primary cultures $(48,49)$, despite its ability to induce TGF $\alpha$ (53). We have observed a similar result in our stem cell growth assay. However, $\gamma$-IFN administered in vivo to psoriatic uninvolved skin resulted in hyperproliferation of the epidermis (54). It is possible that in vivo growth factors (such as GM-CSF, IL-3, or other factors) are sufficiently present in the epidermis to provide the necessary costimulatory signals for $\gamma$-IFN to become growth stimulatory. Similar to our observation on psoriatic uninvolved keratinocyte stem cells, $\gamma$-IFN also exhibits a growth-promoting effect on hemopoietic progenitor cells in the presence of GM-CSF and IL-3 (55).

The observed hyperresponsiveness of psoriatic uninvolved $\beta 1$ integrin $^{+} \mathrm{K} 1 / \mathrm{K} 10^{-}$keratinocytes to the growth-promoting effect of $\mathrm{T}$ cell lymphokines relative to normal keratinocytes is of particular interest. The hyperresponsive status of uninvolved psoriatic stem cells can either be the result of genetic susceptibility or the result of a chronic low grade stimulatory priming of the keratinocytes in vivo. These in vitro data correspond to the clinical observations that, although epidermal hyperplasia occurs in a variety of skin conditions containing activated $\mathrm{T}$ cells (56-58), the most significant hyperproliferation occurs in psoriasis. The finding is also consistent with the Kobner phenomenon, in which inflammation or wounding of psoriatic uninvolved skin can result in development of a psoriatic lesion in the presence of an epidermal infiltrate dominated by $\mathrm{CD}^{+}$ $\mathrm{T}$ cells (59), whereas similar perturbation of normal skin does not result in such changes.

In conclusion, these data characterize a sensitive in vitro model of $\mathrm{T}$ cell and keratinocyte stem cell growth regulatory interactions that appears highly relevant to the human skin disease, psoriasis. According to this model, lesional CD4 ${ }^{+} \mathrm{T}$ cells, through the release of $\gamma$-IFN in the context of other cytokines, act on resting $\beta 1$ integrin $^{+} \mathrm{K} 1 /{\mathrm{K} 10^{-}}^{-}$vimentin ${ }^{-}$keratinocyte stem cells to enter cell cycle $\left(\mathrm{PCNA}^{+}\right)$and subsequently progress through $S / G_{2} / M$, resulting in expansion of the proliferative compartment population. This model may be useful in under- standing regulation of epidermopoiesis and in determining specific markers of genetic susceptibility to psoriasis.

\section{Acknowledgments}

We thank Ted Hamilton for statistical analysis, Carolyn Petersen and Kristine Weber for technical assistance, and Patricia Hopkins and Marsha Gamble for secretarial help.

Support was provided by The Dermatology Foundation, the Medical Research Service of the Department of Veterans Affairs, the Babcock Foundation, and National Cancer Institute University of Michigan Cancer Center Core Grant.

\section{References}

1. Jones, P. H., and F. M. Watt. 1993. Separation of human epidermal stem cells from transit amplifying cells on the basis of differences in integrin function and expression. Cell. 73:713-724.

2. Cotsarelis, G., S.-Z. Cheng, G. Dong, T.-T. Sun, and R. M. Lavker. 1989. Existence of slow-cycling limbal epithelial basal cells that can be preferentially stimulated to proliferate: implications on epithelial stem cells. Cell. 57:201-209.

3. Watt, F. M. 1988. Epidermal stem cells in culture. J. Cell Sci. Suppl. 10:85-94

4. Bata-Csorgo, Zs., C. Hammerberg, J. J. Voorhees, and K. D. Cooper. 1993. Flow cytometric identification of proliferative subpopulations within normal human epidermis and the localization of the primary hyperproliferative population in psoriasis. J. Exp. Med. 178:1271-1281.

5. Cairnie, A. B., P. K. Lala, and D. G. Osmond. 1976. Stem Cells of Renewing Cell Populations. Academic Press, Inc., Orlando, FL.

6. Lavker, R. M., and T.-T. Sun. 1982. Heterogeneity in epidermal basal keratinocytes: Morphological and functional correlations. Science (Wash. DC). 215:1239-1241

7. Lavker, R. M., and T.-T. Sun. 1983. Epidermal stem cells. J. Invest. Dermatol. $81: 121 \mathrm{~s}-127 \mathrm{~s}$

8. Christophers, E., R. Parzefall, and O. Braun-Falco. 1973. Initial events in psoriasis: quantitative assessment. Br. J. Dermatol. 89:327-334.

9. Braun-Falco, O., and C. Schmoeckel. 1977. The dermal inflammatory reaction in initial psoriatic lesions. Arch. Dermatol. Res. 258:9-16.

10. Gupta, A. K., O. Baadsgaard, C. N. Ellis, J. J. Voorhees, and K. D. Cooper. 1989. Lymphocytes and macrophages of the epidermis and dermis in lesional psoriatic skin, but not epidermal Langerhans cells, are depleted by treatment with cyclosporin A. Arch. Dermatol. Res. 281:219-226.

11. Stingl, G., K. Wolff, E. Diem, G. Baumgartner, and W. Knapp. 1977. In situ identification of lymphoreticular cells in benign and malignant infiltrates by membrane receptor sites. J. Invest. Dermatol. 69:231-235.

12. Placek, W., M. Haftek, and J. Thivolet. 1988. Sequence of changes in psoriatic epidermis. Immunocompetent cell redistribution precedes altered expression of keratinocyte differentiation markers. Acta Dermato-Venereol. (Stockh.). 68:369-377.

13. Baker, B. S., A. F. Swain, L. Fry, and H. Valdimarsson. 1984. Epidermal T lymphocytes and HLA-DR expression in psoriasis. Br. J. Dermatol. 110:555564.

14. Bos, J. D., H. J. Hulsebosch, S. R. Krieg, P. M. Bakker, and R. H Cormane. 1983. Immunocompetent cells in psoriasis: in situ immunophenotyping by monoclonal antibodies. Arch. Dermatol. Res. 275:181-189.

15. Morganroth, G. S., L. S. Chan, G. D. Weinstein, J. J. Voorhees, and K. D. Cooper. 1991. Proliferating cells in psoriatic dermis are comprised primarily of $\mathrm{T}$ cells, endothelial cells, and factor XIIIa + perivascular dendritic cells. J. Invest Dermatol. 96:333-340.

16. Uyemura, K., M. Yamamura, D. F. Fivenson, R. L. Modlin, and B. J. Nickoloff. 1993. The cytokine network in lesional and lesion-free psoriatic skin is characterized by a T-helper type 1 cell-mediated response. J. Invest. Dermatol. 101:701-705

17. Ellis, C. N., D. C. Gorsulowsky, T. A. Hamilton, J. K. Billings, M. D. Brown, J. T. Headington, K. D. Cooper, O. Baadsgaard, E. A. Duell, T. M Annesley, et al. 1986. Cyclosporine improves psoriasis in a double-blind study. JAMA (J. Am. Med. Assoc.). 256:3110-3116.

18. Nicolas, J.-F., N. Chamchick, J. Thivolet, J. Wijdenes, P. Morel, and J. P Revillard, 1991. CD4 antibody treatment of severe psoriasis [letter]. Lancet. 338:321.

19. Weinshenker, B. G., B. H. Bass, G. C. Ebers, and G. P. A. Rice. 1989 Remission of psoriatic lesions with muromonab-CD3 (Orthoclone OKT3) treatment. J. Am. Acad. Dermatol. 20:1132-1133.

20. Prinz, J., O. Braun-Falco, M. Meurer, P. Daddona, C. Reiter, P. Rieber, and G. Riethmuller. 1991. Chimaeric CD4 monoclonal antibody in treatment of generalised pustular psoriasis. Lancet. 338:320-321. 
21. Poizot-Martin, I., C. Dhiver, C. Mawas, D. Olive, and J. A. Gastaut. 1991. Are CD4 antibodies and peptide T new treatments for psoriasis? [letter]. Lancet. 337:1477.

22. Ackerman, C., K. Abu-Elagd, K. Venkataramanan, J. Fung, S. Todo, T. Starzl, and B. Jegasothy. 1991. Recalcitrant psoriasis and pyoderma gangrenosum treated with FK506. J. Invest. Dermatol. 96:536. (Abstr.)

23. Morhenn, V. B., E. A. Abel, and G. Mahrle. 1982. Expression of HLADR antigen in skin from patients with psoriasis. J. Invest. Dermatol. 78:165168.

24. Gottlieb, A. B., A. D. Luster, D. N. Posnett, and D. M. Carter. 1988. Detection of a gamma interferon-induced protein IP-10 in psoriatic plaques. $J$. Exp. Med. 168:941-948.

25. Singer, K. H., D. T. Tuck, H. A. Sampson, and R. P. Hall. 1989. Epidermal keratinocytes express the adhesion molecule intercellular adhesion molecule-1 in inflammatory dermatoses. J. Invest. Dermatol. 92:746-750.

26. Baadsgaard, O., A. K. Gupta, R. S. Taylor, C. N. Ellis, J. J. Voorhees, and K. D. Cooper. 1989. Psoriatic epidermal cells demonstrate increased numbers and function of non-Langerhans antigen-presenting cells. J. Invest. Dermatol. 92:190-195.

27. Griffiths, C. E. M., J. J. Voorhees, and B. J. Nickoloff. 1989. Characterization of intercellular adhesion molecule-1 and HLA-DR expression in normal and inflamed skin: modulation by recombinant gamma interferon and tumor necrosis factor. J. Am. Acad. Dermatol. 20:617-629.

28. Schlaak, J. F., M. Buslau, W. Jochum, E. Hermann, M. Girndt, H. Gallati, K.-H. Buschenfelde, and B. Fleischer. 1994. T cells involved in psoriasis vulgaris belong to the Th1 subset. J. Invest. Dermatol. 102:145-149.

29. Baadsgaard, O., P. Tong, J. T. Elder, E. R. Hansen, V. Ho, C. Hammerberg, G. Lange-Vejlsgaard, D. A. Fox, G. Fisher, et al. 1990. UM4D4+ (CDw60) T cells are compartmentalized into psoriatic skin and release lymphokines that induce a keratinocyte phenotype expressed in psoriatic lesions. J. Invest. Dermatol. 95:275-282.

30. Strange, P., K. D. Cooper, E. R. Hansen, G. Fisher, J. K. Larsen, D. Fox, C. Krag, J. J. Voorhees, and O. Baadsgaard. 1993. T-lymphocyte clones initiated from lesional psoriatic skin release growth factors that induce keratinocyte proliferation. J. Invest. Dermatol. 101:695-700.

31. De Luca, M., G. Pellegrini, S. Bondanza, O. Cremona, P. Savoia, R. Cancedda, and P. C. Marchisio. 1992. The control of polarized integrin topography and the organization of adhesion-related cytoskeleton in normal human keratinocytes depend upon number of passages in culture and ionic environment. Exp. Cell Res. 202:142-150.

32. Marcelo, C. L., E. A. Duell, L. M. Rhodes, and W. R. Dunham. 1992. In vitro model of essential fatty acid deficiency. J. Invest. Dermatol. 99:703-708.

33. Cooper, K. D., C. Hammerberg, O. Baadsgaard, J. T. Elder, L. S. Chan, D. N. Sauder, J. J. Voorhees, and G. Fisher. 1990. IL-1 activity is reduced in psoriatic skin: decreased IL-1 alpha and increased non-functional IL-1 beta. $J$. Immunol. 144:4593-4603.

34. Cooper, K. D., C. Hammerberg, O. Baadsgaard, J. T. Elder, L. S. Chan, R. S. Taylor, J. J. Voorhees, and G. Fisher. 1990. Interleukin-1 in human skin: dysregulation in psoriasis. J. Invest. Dermatol. 95:24S-26S.

35. Potten, C. S., and R. J. Morris. 1988. Epithelial stem cells in vivo. J. Cell Sci. Suppl. 10:45-62.

36. Chang, E. Y., C. Hammerberg, G. Fisher, O. Baadsgaard, C. N. Ellis, J. J. Voorhees, and K. D. Cooper. 1992. T-cell activation is potentiated by cytokines released by lesional psoriatic, but not normal, epidermis. Arch. Dermatol. 128:1479-1485

37. Barrandon, Y., and H. Green. 1985. Cell size as a determinant of the clone-forming ability of human keratinocytes. Proc. Natl. Acad. Sci. USA. 82:5390-5394.

38. Kaplan, G., G. Walsh, L. S. Guido, P. Meyn, R. A. Burkhardt, R. M. Abalos, J. Barker, P. A. Frindt, T. T. Fajardo, R. Celona, and Z. A. Cohn. 1992. Novel responses of human skin to intradermal recombinant granulocyte/ macrophage-colony-stimulating factor: Langerhans cell recruitment, keratinocyte growth, and enhanced wound healing. J. Exp. Med. 175:1717-1728.

39. Hofbauer, R., and D. T. Denhardt. 1991. Cell cycle-regulated and prolifera- tion stimulus-responsive genes. Crit. Rev. Eukaryotic Gene Expression. 1:247300

40. Kurki, P., M. Vanderlaan, F. Dolbeare, J. Gray, and E. M. Tan. 1986. Expression of proliferating cell nuclear antigen (PCNA)/cyclin during the cell cycle. Exp. Cell Res. 166:209-219.

41. Watt, F. M., and P. H. Jones. 1994. Human epidermal stem cells. J. Cell. Biochem. Suppl. 18B:173. (Abstr.)

42. Rytina, E., and F. M. Watt. 1994. Lineage analysis in cultured human keratinocytes. J. Cell. Biochem. Suppl. 18B:188. (Abstr.)

43. Zambruno, G., G. Girolomoni, M.-J. Staquet, D. Schmitt, and A. Giannetti. 1988. CDw29 expression on Langerhans cells and on basal keratinocytes. In The Langerhans Cell. J. Thivolet and D. Schmitt, editors. John Libbey \& Company Ltd./London. 159-165.

44. Zambruno, G., V. Manca, M. L. Santantonio, D. Soligo, and A. Giannetti. 1991. VLA protein expression on epidermal cells (keratinocytes, Langerhans cells, melanocytes ): a light and electron microscopic immunohistochemical study. Br. J. Dermatol. 124:135-145.

45. Dover, R., and N. A. Wright. 1991. The Cell Proliferation Kinetics of the Epidermis. In Physiology, Biochemistry, and Molecular Biology of the Skin. L. A. Goldsmith, editor. Oxford University Press, New York. 239-265.

46. Morris, R. J., and C. S. Potten. 1994. Slow cycling (label-retaining) epidermal cells behave like clonogenic stem cells in vitro. Cell Proliferation. 27:279-289.

47. Hancock, G. E., G. Kaplan, and Z. A. Cohn. 1988. Keratinocyte growth regulation by the products of immune cells. J. Exp. Med. 168:1395-1402.

48. Nickoloff, B. J., R. S. Mitra, J. T. Elder, G. J. Fisher, and J. J. Voorhees. 1989. Decreased growth inhibition by recombinant gamma interferon is associated with increased transforming growth factor-alpha production in keratinocytes cultured from psoriatic lesions. Br. J. Dermatol. 121:161-174.

49. Baker, B. S., A. V. Powles, H. Valdimarsson, and L. Fry. 1988. An altered response by psoriatic keratinocytes to gamma interferon. Scand. J. Immunol. 28:735-740

50. Volc-Platzer, B., P. Valent, T. Radaszkiewicz, P. Mayer, P. Bettelheim, and K. Wolff. 1991. Recombinant human interleukin 3 induces proliferation of inflammatory cells and keratinocytes in vivo. Lab. Invest. 64:557-566.

51. Smith, C. H., R. W. Groves, E. L. Ross, J. N. W. N. Barker, and D. M MacDonald. 1993. Effect of granulocyte macrophage-colony stimulating factor (GM-CSF) on Langerhans cells in vivo. J. Invest. Dermatol. 100:490. (Abstr.)

52. Schwartz, M., S. Braunstein, G. Kaplan, Z. Cohn, A. B. Gottlieb, and J. G. Krueger. 1993. GM-CSF activates regenerative epidermal growth and stimulates keratinocyte proliferation in human skin in vivo. J. Invest. Dermatol. 100:494. (Abstr.)

53. Nickoloff, B. J., T. Y. Basham, T. C. Merigan, and V. B. Morhenn. 1984. Antiproliferative effects of recombinant alpha- and gamma-interferons on cultured human keratinocytes. Lab. Invest. 51:697-701.

54. Fierlbeck, G., G. Rassner, and C. Muller. 1990. Psoriasis induced at the injection site of recombinant interferon gamma. Results of immunohistologic investigations. Arch. Dermatol. 126:351-355.

55. Caux, C., I. Moreau, S. Saeland, and J. Banchereau. 1992. Interferongamma enhances factor-dependent myeloid proliferation of human CD34+ hematopoietic progenitor cells. Blood. 79:2628-2636.

56. Morhenn, V. B. 1988. Keratinocyte proliferation in wound healing and skin diseases. Immunol. Today. 9:104-107.

57. Kaplan, G., M. D. Witmer, I. Nath, R. M. Steinman, S. Laal, H. K. Prasad E. N. Sarno, U. Elvers, and Z. A. Cohn. 1986. Influence of delayed immune reactions on human epidermal keratinocytes. Proc. Natl. Acad. Sci. USA. 83:3469-3473.

58. Kaplan, G., A. Nusrat, E. N. Sarno, C. K. Job, J. McElrath, J. A. Porto, C. I. Nathan, and Z. A. Cohn. 1987. Cellular responses to the intradermal injection of recombinant human gamma-interferon in lepromatous leprosy patients. Am. J. Pathol. 128:345-353.

59. Baker, B. S., A. V. Powles, S. Lambert, H. Valdimarsson, and L. Fry 1988. A prospective study of the Koebner reaction and T lymphocytes in uninvolved psoriatic skin. Acta Dermato-Venereol. (Stockh.). 68:430-434. 